\title{
GROWING PROSPECTIVE ENTERPRENEURS IN UNIVERSITIES
}

\author{
Zulhawati, Ifah Rofiqoh, and Lia Faj'rina Binuril Hidayati, and Meiliyah Ariani \\ Universitas Teknologi Yogyakarta, Indonesia. \\ Universitas Islam Negeri Sunan Kalijaga, Indonesia. \\ Universitas Prof. Dr.Moestopo(Beragama), Indonesia. \\ zulhawati@uty.ac.id
}

\begin{abstract}
The increasingly fierce competition of human resources forced universities to prepare graduates who had to have hard skills and soft skills. To reduce unemployment, lack of confidence, lack of understanding of scientific actualization, and other obstacles faced by college graduates, one of the programs implemented at UTY is providing entrepreneurial provisions. Entrepreneurship Development Program (PPK) through various stages is a relationship among students, entrepreneurship, business world and UTY. Support and commitment to entrepreneurship development at UTY are developed through the Field of Entrepreneurship including creativity, innovation and entrepreneurship by providing incubation support to grow and equip students in implementing the business world and entrepreneurial spirit.
\end{abstract}

Keywords: Entrepreneurs, Students, Entrepreneurship, Business World

\section{INTRODUCTION}

There are still many students who have not been moved or care about conditions outside their environment, they are less able to see or read innovative opportunities that can be developed in order to improve their competence and skills. Potential students who have not taken advantage of the opportunities and time to fill their creative thinking and activities can still be seen from the habit of only going to college, eating, sleeping, gaming,watching television and various entertainment programmes. To open the students' minds and touch the intellectual abilities and activities there should be ways so that students' abilities and thoughts can be actualized. The Entrepreneurship Development Program (PPK) which is instilled through academic and non-academic activities in the UTY environment is expected to be able to mobilize the potentials and creativity of students in achieving good learning, working and career opportunities.

Activities that have been carried out including UTY entrepreneurship business proposal competition to inspire students' interest and motivation to be able to be independent entrepreneurs. Entrepreneurship development both academically and non-academically is expected to change the pattern of college graduates as job seekers to become developers, creators and opening job opportunities. UTY students and alumni can think more creatively to develop themselves to face the increasingly fierce work and business competition. Other activities to support the success of student entrepreneurship are by conducting mentoring (business mentoring and consulting) and entrepreneurship gathering to be able to provide color and motivation for students to always open their horizons and creativity in building a career foundation as students and as graduates.

With a selection model of proposals and adequate business presentations, of the many proposals coming from students, especially from the PKM / PKMK team who are developing the business pilot, are guided, directed, assisted by management and strengthened in running or implementing their business. Students from all faculties are netted and socialized to try to make business proposals that will later be developed or evaluation of student business activities that are already running. Most of these student activities are made in 2 categories namely the business category that will be initiated (incubator) and the joint business category of students who are already running.

Expectations from this Entrepreneurship Development Program will emerge various pioneering businesses by students. Because this student's business is still under five years old (toddlers), moral support, management, strong supervision skills and networking or relations support are very important to support the existence of the business. Various obstacles and weaknesses are often encountered in running a business startup.

\section{IMPLEMENTATION METHOD}

\section{Tenants Recruitment}

To get new prospective entrepreneurs, recruitment is carried out by conducting a selection pattern with a business proposal program and a visit to the PKM / PKMK program. Sosialization and selection of proposals carried out with the assessment criteria is the implementation of a business that is feasible to be developed and the motivational spirit of the prospective participants is the basic benchmark of the receipt of the business proposal. In the initial stage, recruitment is taken by students from several majors who are developing or starting new 
businesses. The business proposals that are submitted are then selected. The selection included administration selection, presentation of business proposals, feasibility studies and business visits for students who have developed businesses.

\section{Implementation of the Entrepreneurship Development Program}

Selected tenants will carry out the following activities: (1) Business proposal analysis development program: in this program tenant participant students are given directions in various steps in preparing good business proposals ranging from situation analysis, opening opportunities, production analysis, marketing analysis, human resource analysis and feasibility analysis of each step of the work process in business;

(2) Motivation development training (AMT) in this activity all tenant participants will be given a mental, motivational, physical and spiritual provisioning in running a business that will be or is being pioneered. In this activity participants are trained with the material: business motivation, business management, set the focus on building future goals and the ability to build teams and business communication;

(3) Entrepreneurship training: in this stage training is given on how to manage human resources, production and marketing skills, in addition to management materials, practical experiences from successful entrepreneurs in their business are also provided;

(4) Apprenticeship in Industry Partners . This program also helps students of tenant participants who are starting a business or open businesses are given knowledge and experience through visits, internships and bring in practitioners in accordance with the fields in which students are involved so that students in running their businesses and businesses can have more broad insight, aspects Observe, Imitate and Modify (ATM) can be applied from this program to be implemented in its business program;

(5) Independent Business Implementation Program from the steps that have been carried out carefully from surveys, business analysis and material and HR preparation, students conduct the practice / realize business process in accordance with the project developed with the location, products to sell, potential the market to be worked on as well as business management. From this point the Entrepreneurship Development Program continues to provide direction in determining the best steps to make a business successful;

(6) The Guidance and Evaluation Pattern Support and direction from an expert or consultant is very valuable in providing input and suggestions for the progress of a business. This program is carried out so that the direction in trying to be independent will continue to run and grow;

(7) Supervision and Monitoring for tenants to evaluate and share fellow tenants and supervisors;

(8) The pattern of providing technological assistance to accelerate the process of successfully building a business, whether goods, services or services will be easy to market if assisted with marketing via e-commerce, if these businesses can be assisted in building e-commerce information on products, services and other services will be more easily and quickly spread. With the help of this program, it will clearly help save aspects of distribution and manpower to handle marketing;

(9) Problem solving method In this KDP implementation pattern the problem solving method is carried out by conducting a SWOT analysis (Strengths, Weaknesses, Opportunities and Challenges)

\section{Collaboration with similar partner institutions outside the Universities}

The program aims to develop networks of fellow institutions outside the campus and to partner with various private and government agencies to work together and contribute together in building successful work programs. For this reason, this program continues to be open and always improves friendship with partner institutions from other tertiary institutions, business financing institutions, social institutions and government and private institutions as well as entrepreneurs. Some collaboration media with similar partner institutions are bridged through cooperation by the Yogyakarta Provincial Education Office by holding entrepreneurship and business sharing activities for Lecturers in all PTN-PTS throughout DIY Province and DIY Provincial Student Entrepreneurship program. Collaboration with Bank Mandiri in the Mandiri Entrepreneurial program. Collaboration with Kadin and HIPMI DIY Province and DIY Kemenkop.

\section{RESULT AND DISCUSSION}

The Entrepreneurship Development Program at UTY successfully prepares prospective entrepreneurs in the culinary, creative and fashion industries. The sustainability of this program will be developed by forming an alumni organization for the UTY Entrepreneurship Development Program to become an entrepreneur community so that it can foster younger siblings in developing entrepreneur incubators at UTY. which can bridge students to develop and pioneer independent businesses and can provide management and financing solutions. Utilizing facilities and facilities to develop students' expertise and creativity in utilizing and growing independent businesses that can be managed while still students or after graduation. 


\section{CONCLUSSION}

By recruiting in the form of selection, development and analysis of proposals, entrepreneurship training and mentoring, entrepreneurial practices, industrial apprenticeship, implementation, mentoring and providing technological assistance to problem solving consultations and making collaborations with partner institutions off campus to develop networks can be used as a driving force for prospective entrepreneur from campusS.

\section{ACKNOWLEDGEMENTS}

Thank you to Kemenristek Dikti and LPPM UTY for providing opportunities and financial support in the implementation of the Entrepreneurship Development Program.

\section{REFERENCES}

Kertajaya,Hermawan. (1994). Marketing Plus 2 Jalur Sukses untuk Bisnis, Pustaka Sinar Harapan, Jakarta Lee, Jackly. (2009). 101 Kunci Sederhana Mengembangkan Bisnis dari Rumah,Bookmarks Press, Yogyakarta Maxwell, C. John. (2002). The 17 Essential Qualities of a Team Player, Prestasi Pustaka,Jakarta Kasali, Rhenald. (2011). Wirausaha Muda Mandiri, PT Gramedia Pustaka Utama,Jakarta Kasali, Rhenald. (2012). Re-Code Your Change DNA,PT Gramedia Pustaka Utama,Jakarta Rohkmat. (2012). Manajemen Pemasaran ,Kalam Press,Yogyakarta Nurastuti, Wiji. (2011).Teknologi Perbankan, Graha Ilmu,Yogyakarta Mansur, Yusuf.. (2012). Semua Bisa Jadi Pengusaha, Zikrul Hakim, Jakarta Zulhawati dan Rofiqoh, Ifah. (2014). Manajemen Keuangan dan Etika, Pustaka Pelajar, Yogyakarta Zulhawati dan Rafiqoh, Ifah. (2016). Penganggaran dan Etika Bisnis, Pustaka Pelajar, Yogyakarta 